\title{
PENGARUH RANSUM DENGAN TEPUNG KULIT BUAH NAGA (Hylocereus polyrhizus) TERFERMENTASI TERHADAP KARKAS AYAM BROILER
}

\author{
DEWI, G. A. M. K., I M. NURIYASA, DAN M. WIRAPARTHA \\ Fakultas Peternakan, Universitas Udayana \\ e-mail: elly_unud@yahoo.com
}

\begin{abstract}
ABSTRAK
Penelitian bertujuan untuk mempelajari pengaruh ransum dengan tepung kulit buah naga (Hylocereus polyrhizus) terfermentasi terhadap kualitas karkas ayam broiler telah dilaksanakan selama 4 minggu. Rancangan yang digunakan adalah rancangan acak lengkap (RAL) dengan tiga perlakuan dan enam ulangan dimana setiap ulangan terdiri dari 5 ekor ayam broiler sehingga total ayam yang digunakan sebanyak 90 ekor. Perlakuan yang diberikan yaitu: Ro: ransum tanpa tepung kulit buah naga (TKBN), R1: ransum dengan $5 \%$ tepung kulit buah naga, R2: ransum dengan 7\% tepung kulit buah naga. Variabel yang diamati: bobot potong, berat karkas, daging dada, warna, dan kolesterol daging ayam broiler. Hasil penelitian menunjukkan perlakuan Ro; R1 dan R2 berbeda tidak nyata $(\mathrm{P}>0,05)$ terhadap bobot potong dan berat karkas, sedangkan Ro berbeda nyata terhadap, warna shank, non karkas, serta kolesterol daging ayam broiler dibanding R1 dan R2. Simpulan penelitian ini ransum dengan tepung kulit buah naga (Hylocereus polyrhizus) terfermentasi sampai $7 \%$ tidak berpengaruh terhadap bobot karkas dan bagian-bagian karkas tetapi berpengaruh terhadap bagian punggung karkas, non karkas, warna shank, dan menurunkan kolesterol daging broiler.
\end{abstract}

Kata kunci: broiler, karkas, kolesterol, buah naga, daging

\section{EFFECT OF RATIONS WITH DRAGON FRUIT SKIN (Hylocereus polyrhizus) FLOUR FERMENTATION ON BROILER CARCASS}

\begin{abstract}
The aim of this research is to study the effect of ration with flour dragon fruit skin (Hylocereus polyrhizus) fermented on broiler carcass quality has been carried out for 4 weeks.The design used was Completely Randomized Design with 3 treatments, 6 replications in which each replication consisted of 5 broiler chickens so that the total chicken used was 90 heads. The treatment were: Ro: ration fruit without dragon fruit skin flour, R1: ration with $5 \%$ fermentation dragon fruit skin flour, R2: ration with $7 \%$ fermentation dragon fruit skin flour.Variabel observed: slaughter weight, carcass weight, parts of carcass, shank color and cholesterol meat . The results showed treatment of Ro; R1 and R2 are not significantly different $(\mathrm{P}>0,05)$ to slaughter weight, carcass weight, while Ro is significantly different to shank color, and cholesterol meat $(\mathrm{P}<0,05)$ compared to $\mathrm{R} 2$ and $\mathrm{R} 3$. Conclusion of this study ration with dragon fruit skin flour (Hylocereus polyrhizus) fermented to $7 \%$ did not affect carcass weight and carcass parts but giving significant effect on parts of the carcass back, shank color, non carcass and decrease cholesterol broiler meat.
\end{abstract}

Keywords: broiler chicken, carcass weight, cholesterol meat, dragon fruit flour, meat color

\section{PENDAHULUAN}

Pakan merupakan bagian penting dalam suatu usaha peternakan karena biaya yang dikeluarkan pada suatu usaha peternakan untuk pakan merupakan biaya yang terbesar yaitu mencapai 60\% - 70\%. Ayam broiler yang dipelihara intensif sangat memerlukan ransum agar pertumbuhan sesuai dengan potensi genetik lebih baik dan sehat memerlukan pakan yang berkualitas.

Potensi dari tanaman buah naga sangat baik terlihat dari permintaan yang terus meningkat di masyarakat, teknik budidaya mudah serta iklim di Indonesia sangat cocok untuk berkembangnya tanaman buah naga. Meningkatnya kebutuhan buah naga untuk konsumsi 
menyebabkan limbah kulit buah naga semakin meningkat. Menurut Citramukti (2008) menyatakan bahwa bagian dari buah naga terdiri dari $65-70 \%$ buahnya dan 30-35\% merupakan kulit. Kulit buah naga mengandung potensi sangat besar baik sebagai sumber energi, serat kasar ataupun sumber nutrien lainnya. Pemanfaatan kulit buah naga masih jarang atau bahkan belum dimanfaatkan.

Beberapa peneliti menemukan bahwa kulit buah naga memliki kandungan antioksidan. Menurut $\mathrm{Wu}$ et al. (2006) analisis dari kulit buah naga mengandung betasianin yang memberikan warna violet zat warna yang berperan memberikan warna merah. Wiset et al. (2012), buah naga mengandung zat aktif phenol banyak berperan dalam aktivitas biologis seperti antimutagen, antikarsinogenik, antiaging dan antioksidan. Hasil penelitian dari Daniel et al. (2014) memperoleh kandungan serat kasar dari kulit buah naga sebesar 23,39\%. Tingginya kandungan serat kasar merupakan faktor pembatas pemanfaatannya sebagai komponen pakan ternak unggas. Sacharomyces cerevisiae dapat meningkatkan kecernaan pakan berserat dan dapat berperan sebagai probiotik pada unggas (Ahmad, 2005). Peningkatan nilai guna kulit buah naga dapat dilakukan dengan mengaplikasikan biofermentasi dengan memanfaatkan jasa mikroba yaitu memanfaatkan kemampuan dari khamir Sacharomyces cerevisiae yang terkandung dalam ragi tape. Khasiat dari produk fermentasi adalah dapat menekan aktifitas enzim 3-hydroxy-3-methylglutaryl Co-A reduktase yang berfungsi untuk sintesis kolesterol dalam hati (Tanaka et al., 1992).

Menurut Wahyudi dan Hendraningsih (2007), suplementasi Saccharomyces cerevisiae dalam ransum nyata meningkatkan laju pertumbuhan, efisiensi penggunaan ransum, dan mencegah kejadian keracunan pada unggas yang disebabkan oleh aflatoksin atau aflatoxicosis, serta dapat menurunkan jumlah lemak tumbuh ayam broiler (Ketaren et al. 1999). Hasil penelitian Dewi et al. (2014) dan Dewi et al. (2016 dan 2017), aplikasi teknologi fermentasi pemanfaatan Sacharomyces cerevisiae unggul asal ragi sangat potensial dikembangkan. Merujuk dari hasil penelitian penggunaan kulit buah naga terfermentasi Sacharomyces cerevisiae sebanyak 5\%, 7\%, dan 9\% dalam ransum ayam kampung dapat meningkatkan produktivitasnya. Telah dilakukan penelitian pengaruh ransum dengan tepung kulit buah naga (Hylocereus polyrhizus) terfermentasi terhadap karkas ayam broiler.

\section{MATERI DAN METODE}

\section{Waktu dan Tempat Penelitian}

Penelitian diaksanakan di Laboratorium Unggas, Teaching Farm Kampus Bukit, Jimbaran, Badung dan
Laboratorium Nutrisi dan Makanan Ternak Fakultas Peternakan Universitas Udayana selama tiga bulan.

\section{Kandang}

Kandang yang digunakan adalah kandang baterai yang ditempatkan di dalam bangunan berukuran $6 \times 8$ $\mathrm{m}$. Kandang baterai yang digunakan pada penelitian ini sebanyak 20 unit yang masing-masing unit berukuran panjang $0,75 \mathrm{~m}$, lebar $0,5 \mathrm{~m}$, dan tinggi $0,75 \mathrm{~m}$. Tiang dan dinding kandang dibuat dari kayu, bagian alas kandang terbuat dari kawat, sedangkan untuk tempat makanan dan minumnya terbuat dari bambu.

\section{Bahan}

Bahan yang digunakan pada penelitian ini meliputi sampel kulit buah naga merah (Hylocereus polyrhizus) yang masih mentah sebagai sumber bahan yang difermentasi. Saccaromyces $s p$ dari ragi tape sebagai bahan untuk fermentor dari kulit buah naga (Dewi et al., 2016).

Kandungan nutrisi kulit buah naga sebagai berikut: kandungan EM adalah $2020 \mathrm{kkal} / \mathrm{kg}$, protein $\mathrm{kasar}$ $8,79 \%$, lemak kasar $1,32 \%$, serat kasar $25,8 \%$, abu $20.06 \%$, kalsium $1,75 \%$, fosfor $0,30 \%$. Analisis nutrisi kulit buah naga fermentasi sebesar: kandungan EM adalah $2975 \mathrm{kkal} / \mathrm{kg}$, protein kasar 10,79\%, lemak kasar $1,23 \%$, serat kasar $24,50 \%$, abu 17,95, kalsium 2,35\%, fosfor 0,35\% (Dewi et al., 2016).

Tabel 1. Komposisi bahan penyusun ransum dan kandungan nutrien ternak ayam broiler umur 1-5 minggu

\begin{tabular}{lrrr}
\hline \multirow{2}{*}{ Bahan Penyusun Ransum (\%) } & \multicolumn{3}{c}{ Perlakuan } \\
\cline { 2 - 4 } Jagung & \multicolumn{1}{c}{ R0 } & \multicolumn{1}{c}{$\mathrm{R} 1$} & \multicolumn{1}{c}{$\mathrm{R} 2$} \\
\hline Tepung ikan & 81.39 & 40.86 \\
Kacang kedelai & 18,44 & 18,49 & 18,51 \\
Dedak halus & 25,00 & 21,93 & 20,43 \\
Tepung kulit buah naga terfermentasi & 0,00 & 5,00 & 7,00 \\
Minyak & 4,79 & 5,00 & 5,00 \\
Premix & 0,10 & 0,10 & 0,10 \\
CaCo3 & 0,10 & 0,10 & 0,10 \\
Kandungan Nutrien:* & & & \\
Energi termetabolis (kkal/kg)* & 2900 & 2900 & 2900 \\
Protein kasar (\%) & 20,00 & 20,00 & 20,00 \\
Lemak kasar (\%) & 10,35 & 10,14 & 9,95 \\
Serat kasar (\%) & 3,08 & 3,73 & 3,90 \\
Kalsium (Ca) (\%) & 0,65 & 0,73 & 0,80 \\
Fosfor (P) (\%) & 0,67 & 0,64 & 0,60 \\
\hline
\end{tabular}

Keterangan:

1) R0: ransum tanpa tepung kulit buah naga, R1: ransum dengan $5 \%$ tepung kulit buah naga terfermentasi, R2: ransumdengan $\%$ tepung kulit buah naga terfermentasi * Scott et al. (1982)

\section{Rancangan Penelitian}

Penelitian dilaksanakan dengan rancangan acak lengkap (RAL) dengan tiga perlakuan dan lim ulangan, 
dimana tiap ulangan terdiri dari 10 ekor ayam broiler umur 1 minggu. Perlakuan yang diberikan yaitu: Ro: ransum tanpa tepung kulit buah naga, R1: ransum dengan $5 \%$ tepung kulit buah naga terfermentasi, R2: ransum dengan $7 \%$ tepung kulit buah naga terfermentasi.

\section{Variabel yang diamati}

Variabel yang diamati pada penelitian sebagai berikut: bobot potong (g) diperoleh dengan menimbang ayam broiler pada minggu ke 5 ; bobot karkas (g) diperoleh dari menimbang karkas setelah dikurangi dengan kepala, leher, kaki, dan jeroan; bobot recahan karkas: diperoleh dengan menimbang masing-masing bagian bobot dada, bobot paha, bobot punggung, dan bobot sayap. Warna shank diperoleh dari mengukur warna shank kaki ayam menggunakan kipas yolk colour fan dari Roche dalam Soeparno ( 2005).

\section{Kolesterol Daging Ayam Broiler}

Sampel daging diambil dan dianalisis di Laboratorium Nutrisi dan Makanan Ternak Fakultas Peternakan Universitas Udayana menggunakan metode Enzymatic Cholesterol High Performance (CHODPAPKIT) oleh Boehringer (1993).

\section{Analisis Data}

Data dianalisis dengan Anova dan bila terdapat pengaruh yang nyata $(\mathrm{P} 0<0,05)$ dilanjutkan dengan uji Duncant's Multiple Range Test (Steel and Torrie, 1980). Pengolahan data dianalisis menggunakan program SPSS 17.

\section{HASIL DAN PEMBAHASAN}

\section{Pengaruh Perlakuan terhadap Karkas Ayam Broiler}

Hasil penelitian pemberian pakan tanpa (Ro) dan mengandung tepung kulit buah naga dari 5\% (R1) sampai level 7\% (R2) ditunjukkan pada Tabel 2. Ayam broiler yang mendapat perlakuan Ro, R1 dan R2 memiliki bobot potong sebesar 1354,50 g, 1350,00 g dan 1352.17 g secara statistik tidak berbeda nyata $(\mathrm{P}>0,05)$. Bobot karkas perlakuan Ro, R1, dan R2 masing-masing 924,03 g, 946,45 g, dan 944,87 g secara statistik tidak berbeda nyata $(\mathrm{P}>0,05)$. Pada Tabel 2 terlihat perlakuan tanpa penggunaan kulit buah naga terfermentasi (Ro) dan sebanyak $5 \%$ (R1) kulit buah naga terfermentasi serta, sebanyak 7\% (R2) kulit buah naga terfermentasi pada ransum memberikan prosentase karkas masingmasing sebesar $67,77 \%, 68,1 \%$ dan $67,99 \%$ tetapi secara statistik tidak berbeda nyata $(\mathrm{P}>0,05)$ dapat dilihat juga pada Gambar 1. Hal ini disebabkan karena penggunaan ransum mengandung 5\% (R1) dan 7\% (R2) kulit buah naga fermentasi dapat digunakan dengan baik didalam aktifitas saluran pencernaan, dimana fermentasi dapat membuat lingkungan mikroba saluran pencernaan menjadi lebih normal membantu pencernaan lebih baik dan menyebabkan penyerapan nutrisi lebih efisien sehingga nutrisi lebih banyak disimpan dalam daging ayam. Hasil penelitian ini sesuai dengan Jaya (2011), penelitian menggunakan probiotik 0,1\% dapat meningkatkan secara nyata daging karkas. Menurut Mustika et al. (2014) menyatakan kandungan catechin yang terkandung di dalam kulit buah naga merah dapat berfungsi sebagai antibakteri sehingga penyerapan zat makanan dapat lebih optimal.

Tabel 2. Pengaruh perlakuan terhadap karkas, recahan karkas, warna shank, dan kolesterol daging ayam broiler

\begin{tabular}{lcccc}
\hline \multirow{2}{*}{ Variabel } & \multicolumn{3}{c}{ Perlakuan ${ }^{1)}$} & \multirow{2}{*}{ SEM ${ }^{2}$ ) } \\
\cline { 2 - 4 } & R0 & R1 & R2 & \\
\hline Bobot potong (g) & $1354,50^{\mathrm{a}} 3$ ) & $1350,00^{\mathrm{a}}$ & $1352,17^{\mathrm{a}}$ & 1,15 \\
Bobot karkas (g) & $924,03^{\mathrm{a}}$ & $946,45^{\mathrm{a}}$ & $944,87^{\mathrm{a}}$ & 12,13 \\
Persentase karkas & $67,77^{\mathrm{a}}$ & $68,10^{\mathrm{a}}$ & $67,99^{\mathrm{a}}$ & 2,34 \\
Recahan karkas: & & & & \\
Bobot dada (g) & $287,48^{\mathrm{a}}$ & $293,57^{\mathrm{a}}$ & $291,28 \mathrm{a}^{\mathrm{a}}$ & 14,21 \\
Bobot paha (g) & $279,05^{\mathrm{a}}$ & $285,84^{\mathrm{a}}$ & $281,96^{\mathrm{a}}$ & 7,72 \\
Bobot sayap (g) & $123,83^{\mathrm{a}}$ & $126,45^{\mathrm{a}}$ & $124,76^{\mathrm{a}}$ & 8,24 \\
Bobot punggung (g) & $233,67^{\mathrm{b}}$ & $240,59^{\mathrm{a}}$ & $246.87^{\mathrm{a}}$ & 10,26 \\
Non karkas (g) & $404,14 \mathrm{~b}$ & $385,41 \mathrm{a}$ & $390,78 \mathrm{a}$ & 0,12 \\
Warna shank & $6,00^{\mathrm{b}}$ & $7,00^{\mathrm{a}}$ & $7,00^{\mathrm{a}}$ & 0,03 \\
Kolesterol daging & $161,00^{\mathrm{a}}$ & $143,00^{\mathrm{ab}}$ & $135,00^{\mathrm{b}}$ & 6,02 \\
(mg/dl) & & & &
\end{tabular}

Keterangan:

1) R0: ransum tanpa tepung kulit buah naga, R1: ransum dengan $5 \%$ tepung kulit buah naga terfermentasi, R2: ransum dengan7\% tepung kulit buah naga terfermentasi

2) $\mathrm{SEM}=$ Standard Error of the Treatment Means

3) Angka dengan superskrip yang sama pada baris yang sama menunjukkan perbedaan yang tidak nyata $(P>0,05)$

Menurut Wahyudi dan Hendraningsih (2007), suplementasi Saccharomyces cerevisiae dalam ransum nyata meningkatkan laju pertumbuhan, efisiensi penggunaan ransum, dan mencegah kejadian keracunan pada unggas yang disebabkan oleh aflatoksin atau aflatoxicosis. Faktor yang mempengaruhi persentase bobot karkas ayam broiler adalah bobot potong, umur, jenis kelamin ternak (Bell dan Weaver, 2002, Soeparno, 2005, Samadi dan Liebert, 2006).

Pengaruh perlakuan menggunakan kulit buah naga pada perlakuan Ro, R1 dan R2 berturut-turut memiliki bobot non karkas 404,14 g, 385,41 g dan 390,78 g (Tabel 1 dan Gambar 1). Bobot non karkas antara Ro berbeda nyata $(\mathrm{P}<0,05)$ dibandingkan $\mathrm{R} 1$ dan R2. Persentase non karkas ayam broiler tanpa menggunakan kulit buah naga terfermentasi (Ro) sebesar 4,63\% lebih tinggi dari R1 dan 3,31\% lebih tinggi dari R2. Sedangkan atara perlakuan R1 dan R2 bobot non karkas ayam tidak berbeda nyata $(\mathrm{P}>0,05)$. Hal ini disebabkan ransum yang dikonsumsi lebih banyak digunakan untuk bagianbagian non karkas seperti: bulu, darah, leher, kepala, kaki, jeroan, dan organ dalam dari ayam broiler umur 
Bobot Potong, Bobot Karkas, dan Bobot Non Karkas Ayam Broiler Umur 5 Minggu

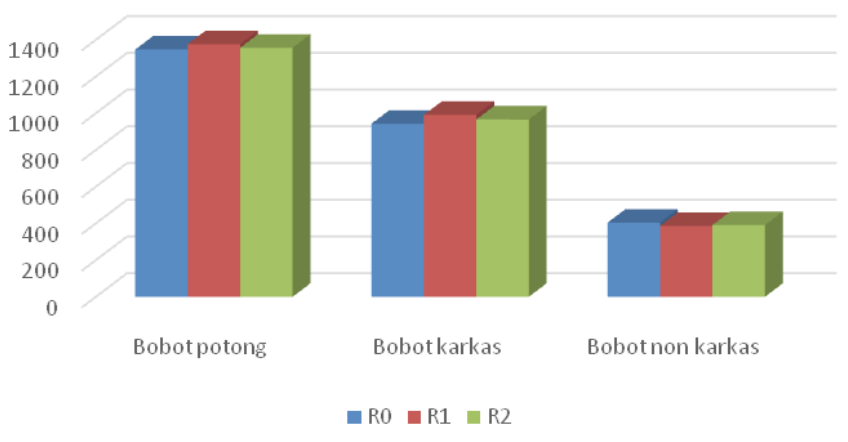

Gambar 1. Grafik bobot potong, bobot karkas dan non karkas ayam broiler

5 minggu (Abubakar dan Nataamijaya, 1999; Soeparno, 2005).

\section{Pengaruh Perlakuan terhadap Bagian-Bagian Karkas, Warna Shank dan Kolesterol Daging}

Hasil penelitian pada Tabel 2 pengaruh perlakuan terhadap bobot bagian-bagian recahan karkas nampak pada bobot dada dari tinggi sampai rendah berturutturut diperoleh sebesar 293,57 g (R1); 291,28 g (R2), dan 287,48 g (Ro) secara statistik tidak berbeda nyata $(\mathrm{P}>0,05)$. Bobot paha masing-masing perlakuan Ro diperoleh sebesar 279,05 g, R1 sebesar 285,84 g dan R2 sebesar 281,96 g secara statistik tidak berbeda nyata ( $\mathrm{P}>0,05)$. Bobot sayap antara perlakuan Ro, R1, dan R2 masing-masing 123,83 g; 126,45 g dan 124,76 g tidak berbeda nyata $(\mathrm{P}>0,05)$. Hasil penelitian menunjukkan pengaruh perlakuan terhadap bobot punggung recahan karkas ayam broiler yang mendapat perlakuan R1 dan R2 masing-masing 2,88\% dan 5,35\% lebih besar nyata $(\mathrm{P}<0,05)$ dari Ro dapat dilihat pada (Tabel 2$)$. Pengaruh perlakuan menggunakan kulit buah naga yang difermentasi Saccaromyces pakan mempengaruhi bagian-bagian karkas yang dihasilkan. bagian dada dan paha berkembang lebih dominan selama pertumbuhan dibandingkan dengan bagian sayap dan bagian punggung.

Hasil penelitian lebih tinggi dariyang diperoleh Astuti (2016) pemberian tepung kulit buah naga terfermentasi mengunakan Aspergillus niger pada ransum untuk ayam broiler memberikan performans baik dan bagian karkas yang baik sampai penggunaan 6\%. Pengaruh perlakuan menggunakan kulit buah naga yang difermentasi Saccaromyces $s p$ memberikan penampilan warna shank berbeda nyata antar perlakuan Ro, dan R1, R2 (Tabel 2.) Perlakuan Ro sebesar 14,29\% lebih rendah dari R1 dan juga 14,29\% lebih rendah dari R2 berbeda nyata $(\mathrm{P}<0,05)$. Warna shank dari ayam broiler banyak dipengaruhi oleh faktor lingkungan dan genetik. Faktor lingkungan yang paling dominan mempengaruhi adalah pakan. Ransum diberikan mengandung kulit buah naga yang mengandung antosianin sumber antioksidan yang memberikan warna violet (Wu et al., (2006) dan menyebabkan warna pada shank ayam broiler (Bell dan Weaver, 2002).

Kandungan kolesterol daging ayam broiler tertera pada Tabel 2. Untuk perlakuan Ro tertinggi $161 \mathrm{mg} / \mathrm{dl}$, R1 sebesar 143 mg/dl, dan R2 sebesar 135mg/dl secara statistik berbeda nyata $(\mathrm{P}<0,05)$. Perlakuan Ro $11,18 \%$ lebih besar dari perlakuan R1, dan 16,15\% lebih tinggi dari R2 secara statistik berbeda nyata $(\mathrm{P}<0,05)$. Hal ini disebabkan karena kulit buah naga terfermentasi pada saluran pencernaan unggas hasil fermentasi membantu pencernaan, menurunkan pembentukan lemak dan penyerapan lemak disaluran pencernaan unggas (Piliang et al., 1990).

Menurut Bintang dan Nataatmijaya (2006) serat kasar pada ransum berfungsi melarutkan lemak tubuh ayam sehingga lemak pada daging ayam lebih rendah, serta dapat menurukan jumlah lemak tumbuh ayam broiler. Disamping itu penurunan lemak tubuh (karkas) juga terjadi karena adanya senyawa asam organik (produk fermentasi) yang dapat menghambat sintesis lipida dalam hati. Tanaka et al. (1992), Bell and Weaver (2002) menunjukkan penggunaan bahan pakan hasil fermentasi dapat menekan aktivitas enzim 3 hidroxy 3 methylglutaryl Co-Areduktase yang berperanan dalam sintesis kolesterol atau lipida dalam hati. Harmayani (2004) melaporkan, khamir yang mampu tumbuh dan mengasimilasi kolesterol dalam usus halus mempunyai potensi sebagai pengontrol kadar kolesterol serum darah inang karena di dalam usus halus terjadi proses absorpsi kolesterol. Mahata et al. (2013) melaporkan penambahan $5 \%$ kulit buah naga dalam ransum dapat meneurunkan kolesterol, LDL, trigliserida, dan mempertahankan HDL secara efektif pada darah ayam broiler.

\section{SIMPULAN}

Berdasarkan hasil penelitian dapat disimpulkan bahwa: ransum dengan tepung kulit buah naga (Hylocereus polyrhizus) terfermentasi sampai $7 \%$ tidak berpengaruh terhadap bobot karkas dan bagian-bagian recahan karkas tetapi pemberian $5 \%$ dan $7 \%$ berpengaruh terhadap berat punggung, non karkas, warna shank, dan menurukan kolesterol daging broiler.

\section{UCAPAN TERIMAKASIH}

Terimakasih diucapkan kepada Rektor Universitas Udayana, Ketua Lembaga Penelitian dan Pengab- 
dian kepada Masyarakat Universitas Udayana, Dekan Fakultas Peternakan Universitas Udayana atas pendanaan penelitian Grup Riset (PNBP) tahun 2017 serta teman peneliti, mahasiswa, dan pegawai yang telah membantu dalam penelitian sampai jurnal ini terbitkan.

\section{DAFTAR PUSTAKA}

Abubakar dan A. G. Nataamijaya. 1999. Persentase Karkas dan Bagian-bagiannya Dua Galur Ayam Broiler dengan Penambahan Tepung Kunyit (Curcuma domestica Val) dalam Ransum. Buletin Peternakan, Edisi Tambahan. Balai Penelitian Ternak Ciawi, Bogor.

Ahmad, R. Z. 2005. Pemanfaatan kamir Saccharomyces cerevisiae untuk ternak. Wartazoa. Vol. 15(1): 45-55.

Astuti, I., I M. Mastika, dan G. A. M. Kristina Dewi. 2016. Performan broiler yang diberi ransum mengandung tepung kulit buah naga tanpa dan dengan Aspergillus niger terfermentasi. Majalah Ilmiah Peternakan. Vol.19(2): 65-70.

Bell, D. D. and Weaver Jr. 2002. Commercial Chicken Meat and Egg Production. $5^{\text {th }}$ ed. Kluwer Academic Publishers, Nor- well, MA.

Bintang. I. A. K. dan Nataatmijaya, A. G. 2006. Karkas dan Lemak Subkutan Broiler yang Mendapat Ransum Suplementasi Tepung Kunyit (Curcuma domestica Val) dan Tepung Lempuyang (Zingiber aromaticum Val). Seminar Nasional Teknologi Peternakan dan Veteriner.

Boehringer, M. 1993. Enzymatic Cholesterol High Performance CHODPAP KIT, France SA. 38240.

Citramukti, I. 2008. Ekstraksi dan Uji Kualitas Pigmen Antosianin pada Kulit Buah Naga Merah (Hylocereuscostaricensis), (Kajian Masa SimpangBuahdan Penggunaan Jenis Pelarut. Skripsi Jurusan THP Universitas Muhammadiyah Malang.

Daniel, R. S., Osfar S., dan Irfan H. D. 2014. Kajian Kandungan Zat Makanan dan Pigmen Antosianin Tiga Kulit Buah Naga (Hylocereus sp) sebagai Bahan Pakan Ternak. Skripsi. Fakultas Peternakan Universitas Brawijaya - Malang.

Dewi, G. A. M. K., I M. Mudita, I M. Nuriyasa, and I W. Wijana. 2014.The effect of inclusion bio-suplement as probiotic in the diet for productivity of bali duct. Proceedings of the AAAP Animal Science Congress. Vol II, 10-14 November 2014.Gajah Mada University, Yogyakarta, Indonesia.

Dewi, G. A. M. K., I M. Nuriyasa, dan I W. Wijana. 2016. Optimalisasi Peningkatan Produksi Ternak Unggas dengan Pemanfaatan Limbah Kulit Buah naga (Hylocereus $s p$ ) Terfermentasi. Laporan Penelitian LPPM. Universitas Udayana.Denpasar.

Dewi, G. A. M. K., I M. Nuriyasa and I W. Wijana. 2017. Production of chicken carcass and noncarcass of kampung chickens who received rations skin dragon fruit flour (Hylocereus polyrhizus) fermented. Proceedings of the $7^{\text {th }}$ Tropical Animal Production, 11-14 September 2017.Gajah Mada University, Yogyakarta Indonesia. Pp.244-250.

Harmayani, E. 2004. Peranan probiotik untuk menurunkan kolesterol. Makalah Seminar Nasional "Probiotik dan Prebiotik sebagai Makanan Fungsional”, tanggal 30 Agustus 2004, Kerjasama Pusat kajian Keamanan Pangan, Lemlit Unud dengan Indonesian Society for Lactic Acid Bacteria (ISLAB), Kampus Bukit Jimbaran, Universitas Udayana, Denpasar.

Jaya, I K. D. 2011. Morphologi and physiologi of pitahaya and it future prospects in Indonesia.Crop Agro. 3:44-50.

Ketaren, P. P., A. P. Sinurat, D. Sainudin, T. Purwadarta, dan I P. Kompiang. 1999. Bungkil inti sawit dan produk fermentasinya sebagai pakan ayam pedaging. Jurnal Ilmu Ternak dan Veteriner 4 (2): 107-112

Mahata, M. E., Mahlil, Y. Fajri, Y. Anditia, R., Yose., R .2014. The utilization of red dragon fruit (Hylocereus polyrhizus) peel as broiler feed. Abstract summary, International Congress and General Meeting. Society for Southeast Asian Agricultural Science (ISSAAS) in Collaboration with SAEDA, Tokyo University of Agriculture and JSTA, Tokyo, Japan.

Mustika, A. I. C., O. Sjofjan., E. Widodo. 2014. Pengaruh Penambahan Tepung Kulit Buah Naga Merah (Hylocereus polyrhyzus) dalam Pakan terhadap Penampilan Produksi Burung Puyuh (Coturnixjaponica). (Skripsi). Universitas Brawijaya Malang.

Piliang, W. G. dan S. Djojosoebagio. 1990. Metabolisme Lemak, Protein dan Serat Kasar. Fisiologi Nutrisi I. Institut Pertanian Bogor Press. Bogor.

Samadi and F. Liebert. 2006. Estimation of nitrogen maintenance requirements and potential for nitrogen deposition in fast-growing chickens depending on ege and sex. Poult.Sci.85:1421-1429.

Scott, M, L., M. C, Nesheim, and R. J Young. 1982. Nutritions of the Chickens, Second Ed, M. L,. Scott and Associates Ithaca, New York.

Soeparno. 2005. Ilmu dan Teknologi Daging, Cetakan ke V, Gadjah Mada University Press.Yogyakarta

Steel, R G. D. and J. H. Torrie. 1980. Principles and Procedures of Statistics. A Biometrical Approach. McGraw Hill Book Co. New York.

Tanaka, K., B. S. Youn, U. Santoso, S. Otan, and M. Sakaida. 1992. Effect of fermented feed products from Chub Mackerel extract on growth and carcass composition, hepatic lipogenesis and on various lipid praction in the liver and thigh muscle of broiler. Anim. Sci. Technol 63: 32-37.

Wahyudi , A. dan L. Hendraningsih. 2007. Probiotik. Konsep, Penerapan, dan Harapan. Buku Ajar. Fakultas Peternakan-Perikanan, Universitas Muhammadiyah, 
Malang.

Wiset, L., Poomsaad, N., and Srilaong, V. 2012. Comparison of antioxidant activity and bioactive compounds of dragon fruit peel from various draying method. World Academy of Science, Engineering and Technology 70446-449.

Wu, L. C., Hsu, H. W., Chen, Y. C., Chiu, C. C., Lin, Y dan Ho, A. 2006. Antioxidant and Antiproliferative Activities of Red Pitaya. Food Chemistry Volume 95, 319-327. 